\title{
1. Corruption and public administration
}

\author{
Adam Graycar
}

\section{COSTS AND HARMS OF CORRUPTION}

Governments exist to deliver value to their communities and to preside over, as Easton (1965) put it, the "authoritative allocation of values". Delivering value is highly contested politically, but whatever ideologies prevail or the courses of action taken, they are underpinned by public administration. Governments may choose to deliver goods and services, or they may choose to regulate their delivery, or may leave them completely alone. They can choose to regulate lightly or heavily, they may regulate the economy, health care, transport, communications, teacher performance, water quality and on and on. If these things are delivered or regulated according to ethical principles and underpinned by good public administration, then the community receives value. If they are tainted by corruption then the community is cheated.

All societies organize themselves to reflect legal, economic, political and social values. Formal mechanisms of administration have been studied throughout history and there is a continual search to find more responsive, more efficient and more effective forms of delivery. Whether the stakes are high or low, there are opportunities for those in administration to pursue their own interests at the expense of those of the community. Research in public policy explores better ways of developing and implementing desirable goals and objectives. This research has no currency when corruption is present. Where there is a lack of integrity or corruption then public administration is deficient and public value suffers.

Globally corruption costs governments and businesses trillions of dollars per year, it adds substantially to costs of goods and services, but most importantly it damages policy objectives and diminishes trust. The catalogue of harms caused by corruption is long. Among other things, corruption hampers economic performance and growth; discourages investment; distorts natural resource development; damages the environment; reduces tax revenue; diminishes quality of life; retards human development; distorts services; weakens judicial integrity and the rule of law; and, of relevance in this book, leads to inefficient public administration.

Defining corruption is not always a fruitful exercise, as there are many nuances and interpretations. In essence it involves trading in entrusted authority, and using one's position to distort outcomes in return for personal gain. It might involve doing wrong things in a public office such as failing to do something that one should do, or doing something permissible, but purposely doing it in an improper manner. Clear definitions are necessary for legal matters relating to corruption and for prosecutions, but not absolutely necessary for improvements in public administration. Definitions and discussion about definitions of corruption abound in the literature (see, for example, de Speville 2010, Dobel 2002, Graycar and Prenzler 2013, Heidenheimer and Johnston 2008, Heywood 2017, Johnston 2005, Klitgaard 1988, Kurer 2015, Mulgan 2012, Philp 2015, Rose-Ackerman and Palifka 2016, Rotberg 2018, Treisman 2000).

Various estimates by the United Nations (2018), the World Economic Forum (2015) and the World Bank (2018), KPMG (2017) and PWC (2019) are that each year corruption costs about 


\section{Handbook on corruption, ethics and integrity in public administration}

5 per cent of global gross domestic product (GDP) (about $\$ 3$ trillion), and adds about 10 per cent to the cost of doing business. Also about $\$ 1$ trillion per year is paid in bribes while the kleptocrats of this world skim or loot about $\$ 40$ billion per year.

In an informative report the International Monetary Fund (IMF) estimates that reducing corruption in one area alone, tax administration, could boost total tax revenues by $\$ 1$ trillion more than they are today, or 1 $1 \frac{1}{4}$ per cent of global GDP (IMF 2019, p.43). Furthermore, the gains would be greater because lower corruption would raise economic growth, further boosting revenues. The IMF conducted a cross-country comparison which confirms that government revenues are significantly lower in countries perceived to be more corrupt. If these countries improved their tax administration and reduced bureaucratic corruption by the same amount as middle-ranked countries did between 1996 and 2017 the extra \$1 trillion would be there.

Chapter 12 by Le and Sarican develops a roadmap for designing effective anti-corruption programmes based on risk mapping of key tax administration functions. In taxation, anti-corruption measures would ultimately boil down to reducing both the motives and opportunities for rent seeking.

A graphic in this IMF report headed "Corruption Leakages in the Public Sector" (p.42, figure 2.3) is drawn to resemble a network of plumbing pipes, which show bureaucratically devised leakages in the system including the following:

- In state-owned companies (and obviously in general services) corrupt bureaucrats negotiate poor contracts.

- When a tax regime is being developed corrupt legislators give away tax exemptions and investment incentives in exchange for bribes.

- When that tax is being collected, corrupt tax administrators collude with taxpayers to let them evade taxes.

- In borrowing and grant arrangements, funds are diverted by corrupt bureaucrats.

- In financial management there can be theft from unmonitored accounts and embezzlement which is enabled by weak financial controls.

- When budget choices need to be made about spending, decisions on investment projects and subsidies are based on bribes and patronage.

- When extrabudgetary funds and public enterprises are governed, there can be a lack of controls, misappropriation of budget and conflicts of interest.

- When procurement decisions are made, there can be bid rigging, overpricing, low-quality products and services, padding of invoices, non-delivery of goods, etc.

- When administering wages and pensions, ghost workers and ghost pensioners often appear.

Of course this is not standard in every bureaucracy, but it is real enough in many of the systems in which the IMF deals. In rich countries the risks are there but the integrity base and the management processes and controls make examples like these the exception rather than the rule.

It is important to determine whether corruption is the norm, or whether it is usually an exception. In some systems corruption is the pervasive custom. Citizens are shaken down regularly by civil servants, some terribly poorly paid and hoping to make ends meet, and some adequately paid, but opportunistic and greedy. Wheelers and dealers issue contracts to friends and cronies, and support infrastructure projects that have little public value. Kleptocratic leaders loot the state and use the treasury as their own piggy bank, often converting funds into substantial assets in offshore countries (Chaikin and Sharman 2009, Sharman 2011). 
Do these events happen all the time? Do the citizens just expect this as part of their everyday routines? Or are these exceptional events? The first point of diagnosis in studying corruption is to determine whether corrupt events are transgressions, or whether they are systemic. If transgressions, the policy and management task is to stop them becoming systemic. If systemic, the developmental process is to turn against corruption as the norm. This process is analysed carefully by Alina Mungiu-Pippidi who argues that the challenge is to move from a situation of bureaucratic particularism to ethical universalism (Mungiu-Pippidi 2015).

There is a long debate about whether corruption is caused by poor systems and exploitable loopholes, or whether it is something that is more about the nature of political systems, and whether things like democratic processes, transparent transactions and genuine representation human rights are the norms (Mungiu-Pippidi 2020). If the task is to move from a system characterized by particularism, solutions lie in the political arena and involve deep democratization (Johnston 2014) and the development of virtuous circles in governance (Mungiu-Pippidi and Johnston 2017). On the other hand if it is the control of transgressions then strengthening the principal/agent relationship is one way forward.

The principal, the politician or minister delegates to the agent the task of implementing the principal's policies. The agent is a public servant who in Weberian terms occupies an office, receives a salary and has certain authority and delegations and delivers as required. If an agent makes discretionary decisions to benefit a client, and if the exchange is hidden, and if the agent receives a payment, it is a corrupt exchange. This assumes that the principal is not corrupt, but the agent may be. There are of course situations in which the principal is corrupt, and situations in which both the principal and agent are corrupt and work in tandem. Sometimes the corrupt event is limited and confined. Sometimes it becomes corrosive as others are drawn into the web of corruption. There is a strong debate about whether developing better processes really has an effect. Persson et al. (2019) argue that this has no impact on corruption control and that collective action is the only way forward. However, where corruption is a transgression, where it is outside the everyday expectations of citizens then building cultures of integrity, making improvements in bureaucratic processes and compliance and enforcement do have a positive impact on corruption.

\section{NOT ALL CORRUPTION IS THE SAME}

Dahlström and Lapuente's excellent book on good governance (2017) opens by expressing the view that governments of high quality act impartially, are non-corrupt and use resources efficiently. They test empirically the components that make this work, and observe that even where many favourable structures are in place, corruption, wasteful spending, rent seeking and ineffectiveness still occur. Their argument is that if the interests, career paths and incentives of politicians and bureaucrats are separate and not interdependent then appropriate checks and balances are more likely.

Not all corruption is the same, and some places are more corrupt than others, whether they be nation states, government departments or police stations. There are many types of corrupt behaviour, and they operate differently in various sectors and places. Corruption also comes in many forms. It is much more than just bribery, which is what comes to mind in most discussions. 


\section{Handbook on corruption, ethics and integrity in public administration}

Corruption includes many types of behaviour, such as bribery, extortion, cronyism, misuse of information and abuse of discretion. These behaviours can take place by way of different activities such as appointing personnel, procuring services, controlling and regulating activities such as issuing permits, licences and concessions, constructing things, etc. Many of these occur concurrently in different sectors such as health, energy, tax administration, justice, etc., and in different places, such as regions, localities or specific workplaces. These concepts, described elsewhere as TASP (types, activities, sectors, places), provide a framework for the analysis of corrupt events in the public sector (Graycar 2015, Graycar and Sidebottom 2012). Table 1.1 illustrates the framework.

Table $1.1 \quad$ Corruption in different dispositions (TASP)

\begin{tabular}{l|l|l|l}
\hline Type & Activities & Sectors & Places \\
\hline Bribery & Issuing licences or permits or & Agriculture & Workplaces \\
Extortion & concessions & Construction & Localities \\
Embezzlement & Hiring people & Customs and immigration & Regions \\
Sexploitation & Managing money & Disaster relief & Countries \\
Self-dealing & Administering justice & Education & etc. \\
$\begin{array}{l}\text { Abuse of discretion } \\
\text { Misuse of information }\end{array}$ & Buying things (procurement) & Energy & \\
Creating or exploiting conflict & Delivering programmes or services & Environment and water \\
of interest & manufacturing) & Fisheries & \\
Patronage/nepotism/cronyism// & Rebuilding things (after a disaster) & Forestry & Health \\
clientelism & etc. & Tax administration \\
etc. & & etc. & \\
\hline
\end{tabular}

This book is very loosely organized around types, activities, sectors and places with the first three parts covering these items, and the fourth exploring responses to corruption in public administration.

There are major differences between corruption in rich countries and corruption in poor countries. In poorer countries bribery and extortion feature prominently in studying corruption types. In richer countries it is much more likely to be hiring friends or family, conflicts of interest, misuse of information or misuse of discretion. This is the face of (principal/agent) corruption in rich countries (Andersson 2008, Graycar 2016, Graycar and Monaghan 2015).

In addition to using TASP as an analytical tool it is useful to distinguish whether the corrupt activity is a consensual activity or an activity in which one party feels extorted. Do two parties come together to exploit the system to the mutual advantage of both, or is one party shaken down by the other ("you won't get the permit to which you are entitled unless you pay me extra")? We can distinguish corruption with theft, where the state loses money - fees, charges, tax revenue, overpriced goods and services, etc. - from corruption without theft where manipulation of process, fixing a contract for a crony, giving a job to a friend, demanding sexual services for a decision are the characteristics. In these cases the state does not lose money. It would have to give a contract anyway, or employ a person for the position.

There are risks posed by the outsourcing of government functions. In the late nineteenth century many private functions were taken over by government such as fire fighting, police, electricity, hospitals and some forms of transport to mention a few. Late in the twentieth century the prevailing view was that government should steer and not row (Osborne and 
Gaebler 1995) and this became the basis for the New Public Management. In analysing these trends Adam Masters (2019) argued that corruption was also outsourced, and with a series of case studies demonstrated three types of outsourced corruption flowing from the outsourcing of functions. These have ramifications for public administration. First, a power of the state is outsourced and then abused by a private party entrusted with that power. Examples of this occur when major procurement items in say defence or information technology are outsourced to consultants to act on behalf of governments. It is really a case of corruption in contract management, a major part of public administration. A second model outlined by Masters is outsourcing as a form of patronage in which powerful groups and oligarchs become rich through kickbacks and special deals for their inner circles. The civil servants are often out of the loop as big decisions about allocation of power and resources are made outside government through patronage networks. A third model involves agents deliberately engaged by governments to act in a corrupt manner on the state's behalf. One finds this in many conflict situations. In Afghanistan for example the United States government paid warlords to keep supply chains open and they did so by massive extortion of protection money, bribery and unaccountability, all with the knowledge of the United States government (Kilcullen 2011). Cases like this are really state support for outsourced corruption.

While corruption is studied extensively, other forms of poor behaviour contribute to less than optimum functioning of government. Misconduct and maladministration make up a much larger proportion of complaints to anti-corruption agencies than do allegations of corruption (Kempf and Graycar 2018). Misconduct occurs when behavioural codes are violated, and these could include bullying and harassment in the workplace, drug or alcohol abuse in the workplace, victimization, poor attitude and even criminal activity such as assault in the workplace. Misconduct is not necessarily less serious than corruption - its effects can be devastating, and responses can come from both internal leadership and external referees.

Maladministration, on the other hand can result in poor programme outcomes, waste of resources and abuse of office. Here public officials might not follow procedures, make inconsistent decisions regardless of evidence and spend public money without due diligence. There is not necessarily a personal kickback to an official but to observers it looks corrupt, unethical or just not right. When a building or a crane collapses because it has not been inspected properly, one has to determine whether the official who signed off was lazy, ignorant, or devious and corrupt.

For a crime to occur, routine activity theory tells us that three elements are necessary: a motivated offender, a target and the absence of a capable guardian (Clarke and Felson 2010). This principle applies equally to public corruption. If any one of these is missing there is no corrupt event. Governance systems in modern states provide target-rich environments for motivated offenders. The guardianship can often be complex, convoluted and incredibly rule bound. However, in Australia (and by implication in other rich countries) experience has shown that lecturing to public officials as though they are potentially corrupt or are criminally inclined is both counter-productive and insulting. My colleague Adam Masters and I explored ways of understanding malfeasance in public administration, especially in low-corruption environments (Graycar and Masters 2018). In societies intolerant of corruption it is harder for corruption to occur at the point of public service delivery. Integrity institutions and systems exist to ensure that organizations perform as expected, and that reporting mechanisms enable citizens to act as frontline watchdogs. 
Most aspects of public administration fall within the following five categories or functions:

- delivery of services to the public;

- financial management;

- resource and service procurement;

- human resource management, hiring people and managing them; and

- issuing of licences, concessions and permits.

Working from actual case studies, for each of these we teased out how to increase the effort required for officials to behave badly; increase the risk of being caught and reduce the rewards of their behaviour; build and value integrity; and raise awareness (Graycar and Masters 2018). Putting these into a matrix and using them in a workshop situation allows participants to focus on their own specific agency situation, as well as developing general strategic approaches. Potential actions are many and varied and can involve, among other things, be transparent in transactions, reduce anonymity, audit finances, audit property, monitor contracts, keep good-quality records, embed and project integrity, use high-standard human resource management practices, assist compliance, neutralize peer pressure and have clear policies.

In an Australian example there was a severe integrity breakdown in a large government department, the Department of Education and Training in the state of Victoria (IBAC 2017). A small group of senior officials corruptly issued contracts, exhibited significant conflict of interest and fostered a culture of harassment and bullying of potential whistle-blowers. There was a culture of fear and intimidation as they captured the vision for the department and overall exhibited many characteristics of misconduct, maladministration and corruption. The department suffered significant reputational loss, as well as financial loss and loss of trust of many stakeholders.

The department responded by issuing a blueprint for renewal which involved three lines of defence (Victoria Department of Education and Training 2017):

- First Line: A culture of integrity underpins everything we do.

- Second Line: Smart systems and controls to oversee and guide our actions.

- Third Line: Independent and robust assurance (audit).

Over 48 pages the report outlines, step by step, how these aspirational statements are to be implemented and inculcated into the department's culture. The strategy starts with employee awareness and a values strategy. Values such as responsiveness, integrity, impartiality, accountability, respect, human rights and leadership were to be rolled out one per month, by way of posters, quick reference sheets, conversation guides, an e-learning module and the distribution of values packs. The report goes through codes, frameworks and systems, and implementation of aspirations such as standard values, investing in people, culture of respect and integrity and setting tone at the top. This is all aimed at changing culture and putting protective processes in place. This example highlights the complexity of the situation and the complexity of the solutions.

This book outlines problems and solutions. It diagnoses situations, provides detailed analysis and proposes ways forward. The authors come from many countries and their experience transcends many domains. The first point however is always an ideological point. Is corruption a reflection of bad administration, or is corruption something deeply embedded in political culture? A leading scholar, Alina Mungiu-Pippidi, notes (2020) that public administration is 
endogenous to, and not a cause of the quality of government. The ideal in corruption prevention is to have the state separate from private interests and to be able to treat citizens equally and impersonally. It is debateable whether this comes about through better management or large-scale political processes. Mungiu-Pippidi (2020) points out that World Bank researchers argue that solving governance with administrative or civil service reform is to confuse the solution with the problem.

She shows that over time corruption has reduced with gains in human rights, transparency and equality, rule of law, elimination of legal privileges, free universal elections, meritocratic recruitment of civil servants and abolition of "offices for sale". These and other instruments of deep democratization took many decades of reform and are not quick fixes to deeply entrenched problems. However, knowing one's starting point is important. In a highly corrupt society many administrative changes seem like band aid solutions. In considerably less corrupt societies they can have a major impact in improving the quality of government.

Anyone with this handbook before them can choose to focus on chapters that seem relevant to them at this moment. There are lessons to be learned from poor countries and rich countries. The authors who have generously contributed to this book have looked both broadly and narrowly, and lessons about the causes of corruption and means to prevent it are here to be shared.

\section{REFERENCES}

Andersson, Staffan. 2008. "Studying the risk of corruption in the least corrupt countries". Public Integrity 10 (3):193-214.

Chaikin, David, and Jason Sharman. 2009. Corruption and money laundering: a symbiotic relationship. New York: Springer.

Clarke, Ronald V., and Marcus Felson. 2010. "The origins of the routine activity approach and situational crime prevention". In The origins of American criminology, edited by F. Cullen, C. Jonson, A. Myer and F. Adler. New Brunswick: Transaction Press.

Dahlström, Carl, and Victor Lapuente. 2017. Organizing Leviathan: politicians, bureaucrats, and the making of good government. Cambridge: Cambridge University Press.

de Speville, Bertrand. 2010. Overcoming corruption: the essentials. Richmond: de Speville and Associates.

Dobel, J. Patrick. 2002. Public integrity. Baltimore, MD: Johns Hopkins University Press.

Easton, David. 1965. A framework for political analysis. Englewood Cliffs, NJ: Prentice Hall.

Graycar, Adam. 2015. "Corruption: classification and analysis". Policy and Society 34 (2):87-96.

Graycar, Adam. 2016. "Corruption and public value". Public Integrity 18 (4):339-41.

Graycar, Adam, and Adam B. Masters. 2018. "Preventing malfeasance in low corruption environments: twenty public administration responses". Journal of Financial Crime 25 (1):170-86.

Graycar, Adam, and Olivia Monaghan. 2015. "Rich country corruption". International Journal of Public Administration 38:586-95.

Graycar, Adam, and Tim Prenzler. 2013. Understanding and preventing corruption. Basingstoke: Palgrave Macmillan.

Graycar, Adam, and Aiden Sidebottom. 2012. "Corruption and control: a corruption reduction approach". Journal of Financial Crime 19 (4):384-99.

Heidenheimer, Arnold J., and Michael Johnston, eds. 2008. Political corruption: concepts and contexts. Piscataway, NJ: Transaction Publications.

Heywood, Paul. 2017. "Rethinking corruption: hocus-pocus, locus and focus". Slavonic and East European Review 95 (1):21-48.

IBAC. 2017. Operation Dunham. www.ibac.vic.gov.au/general/search-results?indexCatalogue $=$ search\& searchQuery $=$ dunham\&wordsMode $=0$ (accessed 19 March 2020). 


\section{Handbook on corruption, ethics and integrity in public administration}

International Monetary Fund (IMF). 2019. Fiscal monitor: curbing corruption. www.imf.org/en/ Publications/FM/Issues/2019/03/18/fiscal-monitor-april-2019 (accessed 19 March 2020).

Johnston, Michael. 2005. Syndromes of corruption: wealth, power, and democracy. New York: Cambridge University Press.

Johnston, Michael. 2014. Corruption, contention and reform: the power of deep democratization. Cambridge: Cambridge University Press.

Kempf, Robin J., and Adam Graycar. 2018. "Dimensions of authority in oversight agencies: American and Australian comparisons". International Journal of Public Administration 41 (14):1145-56.

Kilcullen, David. 2011. The accidental guerrilla: fighting small wars in the midst of a big one. Oxford: Oxford University Press.

Klitgaard, Robert E. 1988. Controlling corruption. Berkeley: University of California Press.

KPMG. 2017. Anti-bribery and corruption. https://assets.kpmg/content/dam/kpmg/xx/pdf/2017/10/anti -bribery.pdf (accessed 19 March 2020).

Kurer, O. 2015. "Definitions of corruption". In Routledge handbook of political corruption, edited by P. Heywood. Abingdon: Routledge, 30-41.

Masters, Adam B. 2019. "Outsourcing corruption". In Global corruption and ethics management: translating theory into action, edited by Carole Jurkiewicz. Lanham, MD: Rowman and Littlefield, 34-41.

Mulgan, Richard. 2012. "Aristotle on legality and corruption". In Corruption: expanding the focus, edited by B. Hindess, M. Barcham and P. Larmour. Canberra: ANU E-press, 25-36.

Mungiu-Pippidi, Alina. 2015. The quest for good governance. Cambridge: Cambridge University Press.

Mungiu-Pippidi, Alina. 2020. "The quality of government and public administration". In Oxford Research Encyclopedia of Public Administration. Oxford: Oxford University Press.

Mungiu-Pippidi, Alina, and Michael Johnston. 2017. Transitions to good governance: creating virtuous circles of anti-corruption. Cheltenham, UK and Northampton, MA, USA: Edward Elgar Publishing.

Osborne, D., and Ted Gaebler. 1995. "Reinventing government". Journal of Leisure Research 27 (3):302-4.

Persson, Anna, Bo Rothstein and Jan Teorell. 2019. "Getting the basic nature of systemic corruption right: a reply to Marquette and Peiffer". Governance 32 (4): 799-810.

Philp, M. 2015. "The definition of political corruption". In Routledge Handbook of Political Corruption, edited by P. Heywood. Abingdon: Routledge, 17-29.

PWC. 2019. "The cost of corruption - too big to ignore". www.pwc.com/gx/en/issues/economy/global -economy-watch/cost-of-corruption.html (accessed 19 March 2020).

Rose-Ackerman, Susan, and Bonnie J. Palifka. 2016. Corruption and government: causes, consequences, and reform. Cambridge: Cambridge University Press.

Rotberg, Robert I. 2018. "Accomplishing anticorruption: propositions and methods". Daedalus 147 (3):5-18.

Sharman, Jason. 2011. The money laundry: regulating criminal finance in the global economy. New York: Cornell University Press.

Treisman, Daniel. 2000. "The causes of corruption: a cross-national study". Journal of Public Economics 76 (3):399-457.

United Nations Secretary General. 2018. Global cost of corruption. https://www.un.org/press/en/2018/ sc13493.doc.htm (accessed 2 February 2019).

Victoria Department of Education and Training. 2017. "Working with integrity". www.ibac.vic.gov.au/ docs/default-source/Responses/det-second-report-to-ibac-september-2017.pdf?sfvrsn=8 (accessed 19 March 2020).

World Bank. 2018. "Combatting corruption". www.worldbank.org/en/topic/governance/brief/anti -corruption (accessed 19 March 2020).

World Economic Forum. 2015. "Corruption, the hidden tax". www.weforum.org/agenda/2015/11/ corruption-the-hidden-tax-on-global-growth/ (accessed 19 March 2020). 